DOI: $10.15193 / \mathrm{zntj} / 2020 / 124 / 344$

\author{
KATARZYNA NEFFE-SKOCIŃSKA, MARTA WÓJTOWICZ, \\ MICHAŁ DĄBROWSKI, DANUTA JAWORSKA
}

\title{
BAKTERIE KWASU OCTOWEGO JAKO POTENCJALNE PROBIOTYKI NOWEJ GENERACJI
}

\begin{abstract}
Streszczenie
Bakterie kwasu octowego (ang. AAB - Acetic Acid Bacteria) występują powszechnie w środowisku. Biorą udział w procesach fermentacji żywności, na której występują naturalnie lub są dodawane celowo dla uzyskania produktu o pożądanych właściwościach. Bakterie te są izolowane m.in. z roślin i produktów z nich wytwarzanych, z fermentowanej żywności i napojów. Mikroorganizmy te w procesie fermentacji wytwarzają wiele związków, wśród których można wyróżnić kwasy glukuronowy i glukonowy, a także inne kwasy organiczne oraz witaminy. Z przedstawionego przeglądu literatury naukowej wynika, że bakterie kwasu octowego mogą mieć zastosowanie terapeutyczne oraz biotechnologiczne i technologiczne. $\mathrm{AAB}$ mają duże znaczenie dla przemysłu spożywczego, zarówno jako bakterie korzystne, jak i szkodliwe $\mathrm{w}$ wielu procesach produkcyjnych, w łańcuchu dostaw i podczas przechowywania produktów. Pomimo dużego potencjału i szerokich możliwości aplikacyjnych wykorzystywanie bakterii kwasu octowego na skalę masową jest jednak wciąż ograniczone.

W ostatnich latach duże zainteresowanie wzbudzają bakterie wykazujące właściwości prozdrowotne i probiotyczne, jednak, aby dany szczep został uznany za probiotyczny, musi spełnić określone wymagania. Bakterie kwasu octowego nie kolonizują jelita grubego, ale wykazują wiele właściwości prozdrowotnych i terapeutycznych, co uzasadnia możliwość ich zaliczenia do grupy probiotyków nowej generacji.
\end{abstract}

Słowa kluczowe: bakterie kwasu octowego (AAB), probiotyki, probiotyki nowej generacji, korzyści zdrowotne

\section{Wprowadzenie}

W ostatnich latach liczba publikacji dotyczących mikroflory bakteryjnej jelit stale wzrasta, a wyniki przeprowadzonych badań jednoznacznie wskazują na występowanie silnej zależności pomiędzy stanem jelit a ogólnym zdrowiem człowieka [8, 21, 35, 39].

Dr inż. K. Neffe-Skocińska, mgr inż. M. Wójtowicz, mgr inż. M. Dąbrowski, dr hab. D. Jaworska, Katedra Technologii Gastronomicznej i Higieny Żywności, Instytut Nauk o Żywieniu Człowieka, Szkoła Główna Gospodarstwa Wiejskiego w Warszawie, ul. Nowoursynowska 159C, 02-776 Warszawa.

Kontakt: katarzyna_neffe_skocinska@sggw.edu.pl 
Bakterie jelitowe są odpowiedzialne za kształtowanie układu odpornościowego, ochronę przed patogenami, regulację wydzielania hormonów żołądkowo-jelitowych, a także biorą udział w prawidłowym funkcjonowaniu mózgu [14, 35, 39].

Z ogólnie przyjętej definicji sformułowanej przez ekspertów Organizacji Narodów Zjednoczonych do spraw Wyżywienia i Rolnictwa (FAO) i Światowej Organizacji Zdrowia (WHO) oraz po poprawkach wprowadzonych przez International Scientific Association for Probiotics and Prebiotics (ISAPP) mianem probiotyków nazywa się „żywe mikroorganizmy, które podane w odpowiedniej liczbie wykazują korzystny wpływ na zdrowie gospodarza", jak również, którym podczas badań in vitro oraz in vivo nadano status GRAS $[9,18]$. W ostatnich latach coraz popularniejsza staje się tematyka probiotyków nowej generacji (Next Generation Probiotic). Można je określić jako drobnoustroje spełniające kryteria mikroorganizmów o właściwościach probiotycznych, jednak niepełniących do tej pory ich funkcji [44]. Ograniczenia te są spowodowane m.in. poprzez wytyczne FAO/WHO, mówiące o pochodzeniu potencjalnych mikroorganizmów probiotycznych z przewodu pokarmowego człowieka. Z drugiej strony w coraz większej liczbie przeprowadzonych badań można znaleźć informacje na temat pozyskiwania nowych szczepów o właściwościach prozdrowotnych, probiotycznych z żywności tradycyjnej, regionalnej, fermentowanej spontanicznie [27, 29, 41, 51, 52]. Obszar poszukiwań „nowych probiotyków” zawęża się głównie do grupy bakterii fermentacji mlekowej $[16,17,44]$. Mniejszą uwagę przywiązuje się do innych grup mikroorganizmów bezpiecznych dla człowieka, znanych od lat, które oprócz przydatności technologicznej wykazują dodatkowo efekt prozdrowotny [13, 16, 17]. Dobrym przykładem probiotyków nowej generacji są bakterie kwasu octowego (ang. Acetic Acid Bacteria - AAB). Mikroorganizmy te występują powszechnie w środowisku. Biorą udział w procesach fermentacji żywności, na której występują naturalnie lub są dodawane celowo dla uzyskania produktu o pożądanych właściwościach. Bakterie $\mathrm{AAB} w$ procesie fermentacji wytwarzają wiele związków, wśród których można wyróżnić kwas glukuronowy i glukonowy, a także inne kwasy organiczne oraz witaminy. $\mathrm{AAB}$ jako organizmy tlenowe nie mogą kolonizować jelita grubego, tak jak bakterie kwasu mlekowego czy komensale, wykazują jednak szereg właściwości prozdrowotnych i terapeutycznych, co uzasadnia postawienie tezy, że szczepy AAB można zaliczyć do grupy probiotyków nowej generacji [3, 6, 7, 13, 16, 17, 32].

Celem pracy była krytyczna analiza dostępnych źródeł literaturowych ze względu na możliwość zaliczenia bakterii kwasu octowego do grupy probiotyków nowej generacji.

\section{Charakterystyka bakterii kwasu octowego}

Bakterie kwasu octowego (ABB) są grupą komórek Gram-ujemnych lub Gramzmiennych, o kształtach od elipsoidalnych do pręcikowych, bezwzględnie tlenowych 
z tlenem jako końcowym akceptorem elektronów. Są to nieprzetrwalnikujące pałeczki o wymiarach $(0,4 \div 1 \mu \mathrm{m}) \times(0,8 \div 4,5 \mu \mathrm{m})$, występujące pojedynczo lub tworzące łańcuszki. Są katalazo-dodatnie i oksydazo-ujemne [22]. Optymalna temperatura wzrostu większości $\mathrm{AAB}$ wynosi $25-30^{\circ} \mathrm{C}$, należą zatem do mikroorganizmów mezofilnych [3]. Bakterie te najlepiej rozwijają się w środowisku, którego $\mathrm{pH}$ wynosi 5,0 $\div$ 6,5. Mają zdolność do namnażania także w środowisku o obniżonym odczynie $\mathrm{pH}$ do ok. $3 \div 4$ [22]. Wytwarzają kwas octowy z etanolu przez dwie kolejne reakcje katalityczne dehydrogenazy alkoholowej (ADH) i dehydrogenazy aldehydowej (ALDH) związanych z błoną. Oprócz alkoholi i aldehydów ABB są zdolne do utleniania różnych cukrów i alkoholi cukrowych, takich jak D-glukoza, glicerol i D-sorbitol [25]. Szczepy Acetobacter mogą dalej utleniać kwas octowy do $\mathrm{CO}_{2}$ i wody w cyklu Krebsa. Dzięki aktywności cyklu Krebsa szczepy Acetobacter są również w stanie metabolizować różne kwasy organiczne, tj. octowy, cytrynowy, fumarowy, mlekowy, jabłkowy, pirogronowy i bursztynowy. Szczepy Gluconobacter nie wykazują takiego działania z powodu nieaktywności dwóch enzymów dehydrogenazy $\alpha$-ketoglutaranu i dehydrogenazy bursztynianowej [31].

Ze względu na dużą różnorodność morfologiczną i fizjologiczną, izolacja, oczyszczanie, identyfikacja oraz konserwacja AAB jest trudna. Do identyfikacji AAB za pomocą różnych mediów można zastosować metody fenotypowe bazujące na zdolnościach fizjologicznych, które zostały obecnie uzupełnione lub zastąpione technikami molekularnymi, związanymi z analizą DNA i RNA [38].

W przypadku większości mikroorganizmów kwas octowy jest szkodliwy w stężeniu $0,5 \%$. Odporność AAB na kwas octowy przy synergistycznym działaniu etanolu jest zależna od szczepu. W warunkach obniżonego $\mathrm{pH}$ AAB nadal rosną i utleniają etanol, nawet gdy cytoplazmatyczne pH obniży się do wartości 3,7. Pod tym względem AAB różnią się od innych acidofilów, z których większość toleruje tylko nieprzepuszczalne dla błony kwasy mineralne (np. $\mathrm{HCl}$ ) i unikają zakwaszenia cytoplazmatycznego [31]. Enzym syntaza cytrynianowa odgrywa kluczową rolę w tej oporności, która detoksykuje kwas octowy przez włączenie do cyklu Krebsa lub cyklu kwasu glioksylanowego. Syntaza cytrynianowa może również dostarczać dużych ilości ATP niezbędnych do przezwyciężenia toksycznego działania kwasu [48]. W poszukiwaniu innych mechanizmów oporności na kwas octowy najbardziej prawdopodobna była pompa wypływowa w błonie cytoplazmatycznej, która wypompowuje kwas octowy z komórki, czego przykładem jest szczep A. aceti IFO 3283 [31].

Bakterie kwasu octowego występują w środowisku bogatym w sacharydy, będącym źródłem węgla potrzebnego do wzrostu. Poszczególne szczepy AAB można spotkać w środowiskach klimatu tropikalnego, śródziemnomorskiego i umiarkowanego [3]. AAB należące do rodzaju Acetobacter są izolowane częściej niż Gluconobacter sp. Yamada i wsp. [10] wyizolowali sześćdziesiąt cztery AAB z pochodzących z Indonezji 
owoców, kwiatów i sfermentowanej żywności oraz zidentyfikowali je jako szczepy Acetobacter (czterdzieści pięć izolatów), szczepy Gluconacetobacter (osiem izolatów) i szczepy Gluconobacter (jedenaście izolatów). AAB wyizolowano również z owoców zebranych w Tajlandii. Izolaty należące do A. pasteurianus wykryto w jabłkach, bananach, winogronach, owocach guawy, owocu jack, limonkach kaffir, pomarańczach, papai, brzoskwiniach, ananasach, marakui, jabłkach, agreście gwiazdkowatym, truskawkach, melonach wodnych, pomidorach i soku palmowym, podczas gdy Acetobacter orientalis i Gluconacetobacter liquefaciens stwierdzono w owocach gwiaździstych i soku palmowym [37]. Naturalnym środowiskiem bytowania bakterii octowych z rodzaju Asaia są tropikalne kwiaty, owady i owoce. Bakterie kwasu octowego izolowano także z ziaren kawy arabiki, fermentowanych ziaren kakaowca, gnijących jabłek, owoców tropikalnych, suszonych owoców, kwiatów, kukurydzy, pyłków kwiatowych, korzeni trzciny cukrowej i z dzikiego ryżu [38].

\section{Wlaściwości prozdrowotne i potencjalnie probiotyczne}

Bakterie $\mathrm{AAB}$ w procesie fermentacji różnych surowców żywnościowych wytwarzają wiele związków, wśród których można wyróżnić kwas glukuronowy, a także inne kwasy organiczne oraz witaminy o istotnie korzystnym wpływie na zdrowie człowieka. Bakterie te mają pewne cechy probiotyków i mogą być uważane za potencjalne probiotyki nowej generacji (tab. 1) [16, 17, 27, 49].

Tabela 1. Zestawienie gatunków ABB o właściwościach potencjalnie probiotycznych

Table 1. List of ABB species with potentially probiotic properties

\begin{tabular}{|c|c|c|}
\hline $\begin{array}{l}\text { Gatunek AAB } \\
\text { AAB species }\end{array}$ & Właściwości / Properties & $\begin{array}{l}\text { Źródło } \\
\text { Source }\end{array}$ \\
\hline $\begin{array}{l}\text { Acetobacter cibi- } \\
\text { nongensis }\end{array}$ & $\begin{array}{l}\text { - zahamowanie wzrostu patogenów / growth inhibition of pathogens } \\
\text { - dobra przeżywalność w modelowym układzie pokarmowym / good } \\
\text { survivability in model digestive system } \\
\text { - wrażliwość na antybiotyki / antibiotic sensitivity }\end{array}$ & $\begin{array}{l}{[16,} \\
17]\end{array}$ \\
\hline $\begin{array}{l}\text { Acetobacter indo- } \\
\text { nesiensis }\end{array}$ & \multirow{2}{*}{$\begin{array}{l}\text { - zahamowanie wzrostu patogenów / growth inhibition of pathogens } \\
\text { - dobra przeżywalność w modelowym układzie pokarmowym / good } \\
\text { survivability in model digestive system } \\
\text { - wrażliwość na antybiotyki / antibiotic sensitivity } \\
\text { - działanie przeciwnowotworowe / anti-cancer effect }\end{array}$} & \multirow{2}{*}{$\begin{array}{c}{[16,} \\
17]\end{array}$} \\
\hline Acetobacter syzygii & & \\
\hline $\begin{array}{l}\text { Gluconobacter } \\
\text { oxydans }\end{array}$ & $\begin{array}{l}\text { - wysoka przeżywalność w modelowym układzie pokarmowym } \\
\text { high survivability in model digestive system } \\
\text { - produkcja glukooligosacharydów / production of gluco- } \\
\text { oligosaccharides } \\
\text { - wysoka oporność na niskie pH / high resistance to low pH } \\
\text { - wrażliwość na antybiotyki / antibiotic sensitivity } \\
\text { - produkcja kwasu glukonowego i glukuronowego / production of } \\
\text { gluconic and glucuronic acid }\end{array}$ & $\begin{array}{l}{[27,} \\
49]\end{array}$ \\
\hline
\end{tabular}


Kluczowymi metabolitami AAB o właściwościach prozdrowotnych są kwasy organiczne [7], np. 1,4-lakton kwasu D-sacharynowego (DSL) jest składnikiem pochodzącym z kwasu D-glukarowego (produkt szlaku GlcUA), który wykazuje właściwości detoksykujące i przeciwutleniające [47]. DSL może hamować aktywność glukozydazy, a tym samym ułatwiać kwasowi glukuronowemu usuwanie substancji toksycznych, w tym substancji rakotwórczych (WWA, niektórych nitrozoamin, aromatycznych amin i toksyn grzybowych), niektórych promotorów nowotworów (hormonów steroidowych) i hepatotoksyn (acetaminofenu). Dodatkowo mogą modulować poziomy estradiolu i innych hormonów steroidowych oraz ich wydalanie $\mathrm{w}$ postaci glukuronidów [23].

Kolejno na uwagę zasługuje kwas glukuronowy (GlcUA), który odgrywa rolę w ksenobiotycznej detoksykacji wątroby. Wykazuje on zdolność łączenia się z cząsteczkami toksyny, ułatwiając ich eliminację z organizmu, co czyni go składnikiem wspomagającym funkcję wątroby. Jest również zaangażowany w eliminację endobiotyczną, m.in. bilirubiny, w ten sposób GlcUA (poprzez glukuronidację) zapobiega toksycznemu działaniu tego pigmentu. GlcUA bierze również udział w zwiększonej biodostępności polifenoli. Fenole są skoniugowane z GlcUA, co ułatwia ich transport i biodostępność. Izoforma UGT1A z rodziny glukuronozylotransferaz, zlokalizowana $\mathrm{w}$ jelitach, jest tą, która bierze udział w glukuronidacji polifenoli [11]. Jako substrat procesu glukuronidacji GlcUA jest również ważny w biotransformacji i ochronie kwasów tłuszczowych przed peroksydacją lipidów, zwłaszcza wielonienasyconych kwasów tłuszczowych, które są niezbędnymi związkami dla organizmu, niezbędnymi składnikami błon komórkowych i prekursorami eikozanoidów. Wielonienasycone kwasy thuszczowe są podatne na działanie reaktywnych form tlenu, wywołując tym samym reakcje łańcuchowe, które uszkadzają cząsteczkę kwasu tłuszczowego. Peroksydacja została uznana za czynnik ryzyka rozwoju niektórych chorób, takich jak miażdżyca, uszkodzenie nerek i choroba Parkinsona [34].

GlcUA jest konieczny dla wielu funkcji organizmu, ponieważ jest składnikiem glikozaminoglikanów (GAG). GAG to grupa związków utworzonych przez dimery składające się z aminocukru (D-glukozaminy lub D-galaktozaminy) i kwasu uronowego (kwasu D-glukuronowego lub kwasu L-iduronowego). Różne GAG powstają w zależności od składników dimeru [34]. Cząsteczki glikozaminoglikanów są częścią macierzy pozakomórkowej wszystkich narządów ciała i pełnią wiele funkcji. GlcUA jest częścią następujących GAG: kwasu hialuronowego, siarczanu chondroityny, heparyny i siarczanu dermatanu. Kwas hialuronowy służy jako środek poślizgowy, amortyzator i jest obecny w wyższych stężeniach w ciele szklistym w oku, tkance łącznej, płynie maziowym stawów i chrząstki [20].

Acetobacter sp. są podgrupą bakterii kwasu octowego, które odgrywają ważną rolę w przemyśle spożywczym, szczególnie w produkcji octu [30]. Wiele dowodów 
świadczy o tym, że ocet ma wartość terapeutyczną, szczególnie w kontrolowaniu poziomu glukozy we krwi w populacjach chorych na cukrzycę lub w stanie przedcukrzycowym [12]. Podobne spostrzeżenia przedstawili Ostman i wsp. [1] po przebadaniu suplementacji kwasem octowym chleba z mąki pszennej jako sposobu obniżenia indeksu glikemicznego. Wykazali oni, że uzupełnienie posiłku chlebem z białej pszenicy z octem zmniejszało poposiłkową odpowiedź glukozy i insuliny we krwi oraz zwiększało subiektywną ocenę sytości.

Fukami i wsp. [43] zaobserwowali, że Acetobacter malorum NCI 1683 (S24) pochodzący z fermentowanego mleka może poprawić funkcje poznawcze u zdrowych osób w średnim wieku i starszych.

Haghshenas i wsp. [16] po zbadaniu składu irańskiego jogurtu tradycyjnego odkryli dwa szczepy należące do rodzaju Acetobacter - A. indonesiensis i A. syzygii, odpowiedzialne za wykazywanie cytotoksyczności w stosunku do linii komórek nowotworowych HeLa (rak szyjki macicy), MCF-7 (rak piersi), AGS (gruczolak żołądka) i HT-29 (gruczolak jelita grubego). Metabolity obu szczepów wykazały znaczące zahamowanie proliferacji komórek bez utrudniania fizjologii normalnych komórek. W innych badaniach Haghshenas i wsp. [17] przebadali szczep Acetobacter cibinongensis 34L, izolowany z tradycyjnego irańskiego twarogu. Szczep 34L wykazywał wrażliwość na antybiotyki, działanie przeciwpatogenne i tolerancję na niskie $\mathrm{pH}$ oraz wysokie stężenie soli żółciowych, czyli spełniał podstawowe wymagania stawiane przez FAO/WHO mikroorganizmom probiotycznym, a autorzy badań rekomendowali jego zastosowanie w przemyśle spożywczym.

Dane epidemiologiczne z Iranu wskazują na mniejszą liczbę zachorowań na nowotwory na terenach wiejskich, gdzie spożywanie regionalnych, tradycyjnie fermentowanych produktów jest częstsze niż w innych rejonach tego kraju [16, 17]. Spośród bakterii kwasu octowego na szczególną uwagę zasługują szczepy Acetobacter aceti i Acetobacter syzygii, które wykazują wysoką przydatność technologiczną oraz właściwości probiotyczne. Szczepy te hamowały namnażanie wybranych bakterii patogennych, tolerowały niskie $\mathrm{pH}$ oraz obecność soli żółciowych i antybiotyków. Ponadto A. syzygii wykazuje wyższy potencjał przeciwnowotworowy wobec komórek rakowych piersi oraz żołądka niż stosowany w ramach chemioterapii taksol. Dodatkowo nie stwierdzono działania toksycznego na zdrowe komórki [16]. Podobne wyniki w przypadku szczepu uzyskano w badaniach jego wpływu na komórki nowotworowe jamy ustnej. A. syzygii hamował rozwój m.in. gruczolaka żołądka i jelita grubego (odpowiednio linie komórkowe AGS i HT-29), nie niszcząc jednocześnie zdrowych komórek. Wykazywał zbliżoną aktywność do cisplatyny, substancji stosowanej w chemioterapii [38].

Z kolei bakterie Acetobacter xylinum, Acetobacter suboxydans są zdolne do syntezy dihydroksyacetonu. Substancja ta wykazuje działanie przeciwpasożytnicze oraz 
detoksykacyjne w zatruciu cyjankami, a także zmniejsza poczucie łaknienia, jak i zawartość tkanki tłuszczowej. Te właściwości wskazują na możliwość wykorzystania wyżej wspomnianych gatunków w przyszłości, w celu opracowania receptur produktów dietetycznych [40].

Do tej pory przeprowadzono niewiele badań dotyczących właściwości potencjalnie probiotycznych szczepów AAB. Jest to temat nowy, jednak wszystkie powyżej przytoczone badania wskazują, na silne właściwości prozdrowotne, w tym probiotyczne, bakterii kwasu octowego.

\section{Zastosowanie w przemyśle spożywczym}

Bakterie kwasu octowego są często postrzegane jako zanieczyszczenie żywności, w tym napojów [3]. AAB mogą niekorzystnie wpływać na produkty spożywcze prowadząc do ich śluzowacenia, zmiany barwy, smaku i zapachu. Zmiany te mogą zachodzić np. w napojach alkoholowych w wyniku przemiany etanolu w kwas octowy [2]. $\mathrm{Z}$ drugiej strony omawiane mikroorganizmy stosowane są do produkcji wielu cennych i znanych od stuleci wyrobów żywnościowych, a naturalne procesy fermentacji z udziałem bakterii AAB są powszechnie stosowane w przemyśle spożywczym [38].

Najbardziej znanym zastosowaniem AAB jest produkcja octu. Na całym świecie produkuje się kilka rodzajów octu różniących się pod względem użytych surowców, technologii i zastosowania. Wyróżnia się dziesięć rodzajów octu, w tym: winny, owocowy, jabłkowy, alkoholowy, zbożowy, słodowy, destylat słodowy, balsamiczny (z dodatkiem moszczu winogronowego) oraz ,inne octy balsamiczne”, które obejmują wszelkie inne substraty pochodzenia rolniczego, takie jak miód lub ryż. Bez wątpienia ocet winny jest najpopularniejszym rodzajem octu rozpowszechnionym $\mathrm{w}$ krajach śródziemnomorskich, chociaż najnowsze trendy gastronomiczne w ostatnich latach, doprowadziły do znacznej ekspansji różnych innych jego odmian [45].

Ocet jest stosowany jako środek aromatyzujący, konserwujący, a w niektórych krajach również jako zdrowy napój. Można go wytworzyć z niemal dowolnego źródła węglowodanów w dwuetapowym procesie fermentacji (pierwszy etap $\mathrm{z}$ udziałem drożdży - fermentacja alkoholowa, drugi etap z udziałem bakterii kwasu octowego fermentacja octowa). Najczęściej używanymi surowcami są jabłka, gruszki, winogrona, miód, syropy, zboża, zhydrolizowane skrobie, piwo i wino. Ocet jest produktem tanim, gdyż do jego produkcji używa się owoców niespełniających norm, sezonowych nadwyżek rolniczych, produktów ubocznych z przetwarzania żywności i odpadów owocowych [24].

Za fermentację octową odpowiedzialne są głównie trzy rodzaje bakterii kwasu octowego, tj. Acetobacter, Gluconacetobacter i Komagataeibacter, jednak stwierdza się również takie gatunki, jak: Acetobacter aceti, Acetobacter malorum, Acetobacter pasteurianus, Acetobacter pomorum, Komagataeibacter europaeus, Komagataeibacter 
hansenii, Komagataeibacter intermedius, Komagataeibacter oboediens, Komagataeibacter xylinus, Komagataeibacter medellinensis i Komagataeibacter maltiaceti [15]. Profil AAB występujący w occie jest bardzo różnorodny, zależny od użytego surowca i cech procesu produkcyjnego [19].

Napojem funkcjonalnym obecnym coraz częściej na rynku jest kombucha. Korzystne działanie tego produktu wynika głównie z obecności polifenoli, związków wytwarzanych podczas fermentacji oraz synergistycznego działania różnych związków występujących $w$ herbacie [42]. Z drugiej strony kombucha to symbiotyczny układ różnych grup drobnoustrojów, w tym bakterii kwasu octowego [7]. Zawarty w nim 1,4-lakton kwasu D-sacharynowego (DSL) oraz kwas glukuronowy są uważane za kluczowe składniki funkcjonalne występujące w napoju kombucha [7, 23, 42].

Kwaśne piwa lambic należą do najstarszych rodzajów piw wciąż warzonych i są produktem spontanicznego procesu fermentacji trwającego od jednego do trzech lat. Proces fermentacji nie jest inicjowany przez zaszczepienie drożdży lub bakterii jako kultur starterowych. Wzrost drobnoustrojów rozpoczyna się podczas nocnego ochładzania gotowanej brzeczki w płytkim otwartym naczyniu. Piwa lambic są tradycyjnie warzone w dolinie rzeki Senne, w pobliżu Brukseli. Warzenie tego piwa tradycyjnie odbywa się tylko w chłodniejszych miesiącach roku, ponieważ zimne noce są potrzebne do obniżenia temperatury brzeczki do ok. $20^{\circ} \mathrm{C}$ w ciągu jednej nocy. Przyjmuje się, że rano po gotowaniu brzeczki zaszczepiona zostaje specyficzna mikroflora pochodząca z powietrza doliny rzeki Senne. Beczki są następnie przechowywane w piwnicy lub w temperaturze otoczenia, tj. zwykle między 15 a $25^{\circ} \mathrm{C}$, a piwo poddawane fermentacji i dojrzewaniu. Produktem końcowym jest niegazowane piwo kwaśne, które służy głównie jako podstawa do piwa gueuze lub jagodowego [46]. Kwaśny charakter piwa wynika z aktywności metabolicznej różnych drożdży, bakterii kwasu mlekowego i bakterii kwasu octowego. Po 3 - 4 miesiącach fermentacji zachodzi faza zakwaszania, która charakteryzuje się rosnącą populacją Pediococcus sp. i czasami Lactobacillus sp., podczas gdy Brettanomyces sp. stają się powszechnie spotykane po $4 \div 8$ miesiącach fermentacji. Końcowa faza dojrzewania rozpoczyna się po 10 miesiącach fermentacji i charakteryzuje się obniżeniem $\mathrm{LAB}$, natomiast $\mathrm{AAB}$ są obecne przez cały okres fermentacji, zwłaszcza w ciepłych miesiącach [33].

Do niedawna występowanie i różnorodność gatunkowa $\mathrm{AAB}$ w produkcji piwa lambic nie były szeroko badane. Uważano, że kwaśny smak piw lambic mógł być związany z produkcją kwasu octowego przez bakterie LAB na drodze heterofermentacji [4]. Wykryto natomiast dwa nowe gatunki AAB (Acetobacter lambici oraz Gluconobacter cerevisiae), które są charakterystyczne dla piw lambic [46]. Wcześniejsza sporadyczna izolacja AAB może wynikać z tego, że będąc organizmami tlenowymi są skoncentrowane na granicy faz powietrze - ciecz w drewnianych beczkach, a zatem są 
pomijane przez klasyczne metody pobierania próbek przez zatkany korkiem otwór do pobierania próbek umieszczony tuż nad dnem na przodzie beczek [4].

Kwas octowy wytwarzany przez tlenowe AAB jest kluczowym metabolitem w procesie fermentacji ziaren kakaowych. Surowe ziarna kakaowe mają nieprzyjemny smak i muszą być fermentowane, suszone i prażone, aby uzyskać pożądany charakterystyczny smak kakaowy. Fermentacja jest zatem pierwszym krokiem w produkcji proszku kakaowego i czekolady. Mikrobiota zaangażowana w naturalną fermentację ziaren kakaowych reprezentuje szereg drożdży (Saccharomyces cerevisiae, Candida tropicalis), bakterii kwasu mlekowego (Lactobacillus cellobiosus, Lactiplantibacillus plantarum) i bakterii kwasu octowego (A. pasteurianus, A. ghanensis, A. senegalensis i Gluconobacter sp.) [36]. AAB utlenia etanol drożdżowy do kwasu octowego [28]. Kwas octowy wytwarzany przez tlenowy AAB jest kluczowym metabolitem w procesie fermentacji ziaren kakaowych. Ten lotny krótkołańcuchowy kwas thuszczowy dyfunduje do ziaren, a to $\mathrm{w}$ połączeniu $\mathrm{z}$ ciepłem wytwarzanym przez egzotermiczną biokonwersję etanolu w kwas octowy powoduje śmierć zarodka nasiennego, zakłócenie wewnętrznej struktury komórkowej ziaren i koniec fermentacji [5]. Z kolei inicjowane są zmiany biochemiczne ziaren, prowadzące do enzymatycznego tworzenia cząsteczek prekursorowych niezbędnych do rozwoju charakterystycznego aromatu, smaku i barwy ziaren $[43,44]$. Te właściwości są dalej rozwijane podczas suszenia, prażenia i końcowego przetwarzania dobrze sfermentowanych ziaren kakaowych [36].

\section{Podsumowanie}

Powszechnie uznaje się, że probiotykami są głównie wyselekcjonowane szczepy bakterii kwasu mlekowego i drożdży, spełniające wymagania określone przez FAO/WHO oraz ISSAP. Z drugiej strony pojawiają się doniesienia opowiadające się za przyjęciem nowych mikroorganizmów do kategorii probiotyków i określenia ich probiotykami nowej generacji.

Probiotyki nowej generacji stanowią grupę mikroorganizmów wykazujących właściwości prozdrowotne, w tym probiotyczne i spełniające szereg wymagań dotyczących skuteczności i bezpieczeństwa ich stosowania. Obiecującą grupę potencjalnych probiotyków stanowią bakterie kwasu octowego. Znalazły one zastosowanie w technologii żywności, m.in. do produkcji napojów i octów. Przedstawiony przegląd literatury wskazuje na liczne korzyści wynikające ze spożycia produktów otrzymanych w wyniku przemian metabolicznych AAB.

Przytoczone w niniejszej pracy wyniki badań przeprowadzonych na wybranych szczepach bakterii kwasu octowego przemawiają za tym, że AAB spełniają część wymagań stawianych probiotykom. Podstawowe kryteria oceny mikroorganizmów probiotycznych, takie jak testy tolerancji na niskie pH i wysokie stężenie soli żółciowych, aktywność antagonistyczna wobec patogenów oraz wrażliwość na antybiotyki czy 
aktywność przeciwnowotworowa potwierdzają ich potencjalne właściwości probiotyczne, prozdrowotne.

Zdefiniowanie pozostałych obligatoryjnych właściwości probiotycznych AAB, poszukiwania poprzez izolację i identyfikację nowych szczepów AAB oraz ocena właściwości prozdrowotnych tych mikroorganizmów, wykraczających poza wytyczne FAO/WHO, jest niezbędne do dalszych rozważań nad poszerzeniem znaczenia terminu „probiotyk” i dołączenia do tej grupy probiotyków nowej generacji.

\section{Literatura}

[1] Aghazadeh Z., Pouralibaba F., Khosroushahi A.Y.: The prophylactic effect of Acetobacter syzygii probiotic species against squamous cell carcinoma. J. Dental Res., Dental Clinics, Dental Prospects, 2017, 11 (4), 208-214.

[2] Antolak H., Kręgiel D.: Bakterie kwasu octowego - istotne zagrożenie w przemyśle spożywczym. Przem, Spoż., 2014, 68 (6), 12-16.

[3] Antolak H., Kręgiel D.: Bakterie kwasu octowego - taksonomia, ekologia oraz wykorzystanie przemysłowe. Żywność. Nauka. Technologia. Jakość, 2015, 4 (101), 21-35.

[4] Camu N., González A., de Winter T., van Schoor A., de Bruyne K., Vandamme P., de Vuyst L.: Influence of turning and environmental contamination on the dynamics of populations of lactic acid and acetic acid bacteria involved in spontaneous cocoa bean heap fermentation in Ghana. Appl. Envir. Microbiol., 2008, 74 (1), 86-98.

[5] De Brito E.X., Pezoa Garcia N.H., Gallao M.I., Cortelazzo A.L., Feveriro P.S., Brage M.R.: Structural and chemical changes in cocoa (Theobroma cacao L) during fermentation, drying and roasting. J. Sci. Food Agric., 2001, 81 (2), 281-288.

[6] De Filippis F., Troise A.D., Vitaglione P., Ercolini D.: Different temperatures select distinctive acetic acid bacteria species and promotes organic acids production during Kombucha tea fermentation. Food Microbiol., 2018, 73, 11-16.

[7] De Roos J., de Vuyst L.: Acetic acid bacteria in fermented foods and beverages. Curr. Opinion Biotechnol., 2018, 49, 115-119.

[8] Dudzińska E.: Wpływ mikroflory jelitowej na rozwój zespołu jelita drażliwego. Medycyna Środowiskowa, 2016, 19 (3), 70-76.

[9] FAO/WHO: Probiotics in Food. Health and Nutrition Properties and Guidelines for Evaluation. [online]. FAO/WHO. Rome 2006. Dostęp w Internecie [20.04.2020.]: http://www.fao.org/tempref/docrep/fao/009/a0512e/a0512e00.pdf

[10] Francois J.A., Starks C.M., Sivanuntakorn S., Jiang H., Ransome A.E., Nam J.-W., Constantine C.Z., Kappock T.J.: Structure of NADH-insensitive hexameric cytrate synthase that resists acid inactivation. Biochemistry, 2006, 45 (45), 13487-13499.

[11] Frati-Munari A.C.: Glicosaminoglicanos en las enfermedades vasculares. Revista Mexicana de Angiología, 2012, 40 (3), 89-99.

[12] Fukami H., Tachimoto H., Kishi M., Kage T., Tanaka Y., Koga Y., Shirasawa T.: Continuous ingestion of acetic acid bacteria: Effect on cognitive function in healthy middle-aged and elderly persons. Anti-Aging Medicine 2009, 6 (7), 60-65.

[13] Guillamón J.M., Mas A.: Acetic Acid Bacteria. In: Biology of Microorganisms on Grapes, in Must and in Wine. Springer, Cham 2017, pp. 43-64. 
[14] Gulas E., Wysiadecki G., Strzelecki D., Gawlik-Kotelnicka O., Polguj M.: Jak mikrobiologia może wpływać na psychiatrię? Powiązania między florą bakteryjną jelit a zaburzeniami psychicznymi. Psychiatria Polska, 2018, 52 (6), 1023-1039.

[15] Gullo M., de Vero L., Giudici P.: Succession of selected strains of Acetobacter pasteurianus and other acetic acid bacteria in traditional balsamic vinegar. Appl. Environ. Microbiol., 2009, 75 (8), 2585-2589.

[16] Haghshenas B., Nami Y., Abdullah N., Radiah D., Rosli R., Khosroushahi A.Y.: Anticancer impacts of potentially probiotic acetic acid bacteria isolated from traditional dairy microbiota. LWT - Food Sci. Technol., 2015, 60 (2), 690-697.

[17] Haghshenas B., Nami Y., Abdullah N., Radiah D., Rosli R., Barzegari A., Khosroushahi A.Y.: Potentially probiotic acetic acid bacteria isolation and identification from traditional dairies microbiota. Int. J. Food Sci. Technol., 2015, 50, 1056-1064.

[18] Hill C., Guarner F., Reid G., Reid G., Gibson G.R., Merenstein D.J., Pot B., Morelli L., Canani R.B., Flint H.J., Salminen S., Calder P.C., Sanders M.E.: The International Scientific Association for Probiotics and Prebiotics consensus statement on the scope and appropriate use of the term probiotic. Nature Rev. Gastroenterology Hepatology, 2014, 11, 506-514.

[19] Jayabalan R., Subathradevi P., Marimuthu S., Sathishkumar M., Swaminathan K.: Changes in freeradical scavenging ability of Kombucha tea during fermentation. Food Chem., 2008, 109 (1), $227-$ 234.

[20] Johnston C.S., White A.M., Kent S.M.: Preliminary evidence that regular vinegar ingestion favorably influences hemoglobin Alc values in individuals with type 2 diabetes mellitus. Diabetes Res. Clin. Pract., 2009, 84 (2), 15-17.

[21] Kościej A., Skotnicka-Graca U., Ozga I.: Rola wybranych czynników żywieniowych w kształtowaniu odporności dzieci. Probl. Hig. Epidemiol., 2017, 98 (2), 110-117.

[22] Kręgiel D., Rygała A., Libudzisz Z.: Bakterie z rodzaju Asaia - nowe zanieczyszczenie smakowych wód mineralnych. Żywność. Nauka. Technologia. Jakość, 2011, 2 (75), 5-16.

[23] Martínez Cruz P., Ibáñez A.L., Monroy Hermosillo O.A., Ramírez Saad H.C.: Use of probiotics in aquaculture. ISRN Microbiol., 2012, \#916845. DOI: 10.5402/2012/916845.

[24] Mas A., Torija M.J., del Carmen García-Parrilla M., Troncoso A.M.: Acetic acid bacteria and the production and quality of wine vinegar. Sci. World J. 2014, \#394671. DOI: 10.1155/2014/394671.

[25] Matsushita K., Toyama H., Adachi O.: Respiratory chains and bioenergetics of acetic acid bacteria. Adv. Micro. Physiol., 1994, 36, 247-301.

[26] Nanda N., Taniguchi M., Ujike S., Ishihara N., Mori H., Ono H., Murooka Y.: Characterization of acetic acid bacteria in traditional acetic acid fermentation of rice vinegar (Komesu) and unpolished rice vinegar (Kurosu) produced in Japan. Appl. Environ. Microbiol., 2001, 67, 986-990.

[27] Neffe-Skocińska K., Dybka-Stępień K., Antolak H.: Izolacja i identyfikacja szczepów bakterii kwasu octowego o potencjalnych właściwościach prozdrowotnych. Żywność. Nauka. Technologia. Jakość, 2019, 3 (120), 183-195.

[28] Nielsen D.S., Teniola O.D., Ban-Koffi L., Owusu M., Andersson T.S., Holzapfel W.H.: The microbiology of Ghanaian cocoa fermentations analysed using culture-dependent and culture-independent methods. Int. J. Microbiol., 2007, 114 (2), 168-186.

[29] Ołdak A., Zielińska D., Rzepkowska A., Kołożyn-Krajewska D.: Comparison of antibacterial activity of Lactobacillus plantarum strains isolated from two different kinds of regional cheeses from Poland: Oscypek and korycinski cheese. BioMed Res. Int., 2017, \#6820369. DOI: $10.1155 / 2017 / 6820369$.

[30] Ostman E., Granfeldt Y., Persson L., Björck I.: Vinegar supplementation lowers glucose and insulin responses and increases satiety after a bread meal in healthy subjects. Eur. J. Clin. Nutr., 2005, 59 (9), 983-988. 
[31] Raspor P., Goranovič D.: Biotechnological applications of acetic acid bacteria. Crit. Rev. Biotechnol., 2008, 28 (2), 101-124.

[32] Romero-Cortes T., Robles-Olvera V., Rodriguez-Jimenes G., Ramírez-Lepe M.: Isolation and characterization of acetic acid bacteria in cocoa fermentation. Afr. J. Microbiol. Res., 2012, 6 (2), 339347.

[33] Roos J., Verce M., Aerts M., Vandamme P., de Vuyst L.: Temporal and spatial distribution of the acetic acid bacterium communities throughout the wooden casks used for the fermentation and maturation of lambic beer underlines their functional role. Appl. Envir., Microbiol., 2018, 84 (7), 1-40.

[34] Safari M.S., Keyhanfar M., Shafiei R.: Investigating the antibacterial effects of some Lactobacillus, Bifidobacterium and Acetobacter strains killed by different methods on Streptococcus mutans and Escherichia coli. Mol. Biol. Res. Commun., 2019, 8 (3), 103-111.

[35] Salehi B., Dimitrijević M., Aleksić A., Neffe-Skocińska K., Zielińska D., Kołożyn-Krajewska D., Sharifi-Rad J., Stojanović-Radić Z., Milton Prabu S., Rodrigues C.F., Martins N.: Human microbiome and homeostasis: Insights into the key role of prebiotics, probiotics, and symbiotics. Crit. Rev. Food Sci. Nutr. DOI: 10.1080/10408398.2020.1760202.

[36] Schwan R.F., Wheals A.E.: The microbiology of cocoa fermentation and its role in chocolate quality. Crit. Rev. Food Sci. Nutr., 2004, 44, 205-221.

[37] Seearunruangchai A., Tanasupawat S., Keeratipibul S., Thawai C., Itoh T., Yamada Y.: Identification of acetic acid bacteria isolated from fruits collected in Thailand. J. Gen. Appl. Microbiol., 2004, $50(1), 47-53$.

[38] Sengun I.Y., Karabiyikli S.: Importance of acetic acid bacteria in food industry. Food Control, 2011, $22(5), 647-656$.

[39] Sharifi-Rad J., Rodrigues C.F., Stojanović-Radić Z., Dimitrijević M., Aleksić A., Neffe-Skocińska K., Zielińska D., Kołożyn-Krajewska D.: Probiotics: Versatile bioactive components in promoting human health. Medicina, 2020, 56 (9), \#433. DOI:10.3390/medicina56090433.

[40] Solieri L., Giudici P.: Vinegars of the World. In: Vinegars of the World. Springer, Milan 2009, pp. $1-16$.

[41] Spinler J.K., Auchtung J., Brown A., Boonma P., Oezguen N., Ross C.L., Luna R.A., Runge J., Versalovic J., Peniche A., Dann S.M., Britton R.A., Haag A., Savidge T.C.: Next-generation probiotics targeting Clostridium difficile through precursor-directed antimicrobial biosynthesis. Infection and Immunity, 2017, 85 (10), \# 00303-17. DOI: 10.1128/IAI.00303-17.

[42] Spitaels F., Li L., Wieme A., Balzarini T., Cleenwerck I., van Landschoot A., de Vuyst L., Vandamme P.: Acetobacter lambici sp. nov., isolated from fermenting lambic beer. Int. J. System. Evol. Microbiol., 2014, 64 (4), 1083-1089.

[43] Stasiak-Różańska L., Błażejak S.: Dihydroksyaceton - charakterystyka, zastosowanie, otrzymywanie. Acta Sci. Polon. Biotechnologia, 2012, 11 (1), 17-27.

[44] Tan H., Zhai Q., Chen W.: Investigations of Bacteroides spp. towards next-generation probiotics. Food Res. Int., 2019, 116, 637-644.

[45] Tesfaye W., Morales M.L., García-Parrilla M.C., Troncoso A.M.: Wine vinegar: Technology, authenticity and quality evaluation. Trends Food Sci. Technol., 2002, 13 (1), 12-21.

[46] Verachtert H., Iserentant D.: Properties of Belgian acid beers and their microflora. Part I. The production of gueuze and related refreshing acid beers. Cerevisia, Belgian J. Brewing Biotechnol., 1995, 20 (1), 37-41.

[47] Vina I., Linde R., Patetko A., Semjonovs P.: Glucuronic acid from fermented beverages: Biochemical functions in humans and its role in health protection. Int. J. Res. Rev. Appl. Sci., 2013, 14 (2), 217-230. 
[48] Wichienchot S., Prasertsan P., Hongpattarakere T., Gibson G.R., Rastall R.A.: In vitro fermentation of mixed linkage gluco-oligosaccharides produced by Gluconobacter oxydans NCIMB 4943 by the human colonic microflora. Curr. Issues Intestinal Microbiol., 2006, 7 (1), 7-12.

[49] Yang Z., Zhou F., Ji B., Li B., Luo Y., Yang L., Li T.: Symbiosis between microorganisms from kombucha and kefir: Potential significance to the enhancement. Appl. Bioch. Biotechnol., 2010, 160 (2), 446-455.

[50] Yetiman A.E., Kesmen Z.: Identification of acetic acid bacteria in traditionally produced vinegar and mother of vinegar by using different molecular techniques. Int. J. Food Microbiol., 2015, 204, 9-16.

[51] Zielińska D., Kołożyn-Krajewska D.: Food-origin lactic acid bacteria may exhibit probiotic properties. BioMed Res. Int., 2018, \# 5063185. DOI:10.1155/2018/5063185.

[52] Zielińska D., Długosz E., Zawistowska-Deniziak A.: Functional properties of food-origin Lactobacillus in the gastro-intestinal ecosystem - in vitro study. Prob. Antimicrob. Proteins, 2019, 11 (3), 820-829.

\section{ACETIC ACID BACTERIA AS POTENTIAL NEXT-GENERATION PROBIOTICS}

\section{S u m m a r y}

Acetic Acid Bacteria (AAB) occur commonly in nature. They participate in fermentation processes of food, where they occur naturally or are purposely added to make a product with desirable properties. They are isolated, inter alia, from plants and plant-produced products, fermented foods and beverages. During the fermentation process those microorganisms produce many compounds; among them are glucuronic and gluconic acids, other organic acids and vitamins. The presented review of scientific literature shows that acetic acid bacteria may have therapeutic, biotechnological and technological applications. In the food industry AABs are highly important as beneficial and the adverse bacteria in many production processes, in the supply chain and during the storage of products. Despite the great potential and wide application possibilities, use of acetic acid bacteria is still limited on a massive scale.

In recent years bacteria with pro-health and probiotic properties have attracted great interest, however a given strain must meet certain requirements to be considered probiotic. Acetic acid bacteria do not colonise the large intestine, but they have many pro-health and therapeutic characteristics, which justifies the possibility of classifying them into a group of next-generation probiotics.

Key words: acetic acid bacteria (AAB), probiotics, next- generation probiotics, health benefits 